Acta Technologica Agriculturae 2

Nitra, Slovaca Universitas Agriculturae Nitriae, 2018, pp. 44-50

\title{
INVESTIGATION OF THE EFFECT OF SOIL MOISTURE CONTENT, CONTACT SURFACE MATERIAL AND SOIL TEXTURE ON SOIL FRICTION AND SOIL ADHESION COEFFICIENTS
}

\author{
Yousef ABBASPOUR-GILANDEH*, Fereshteh HASANKHANI-GHAVAM, Gholamhosein SHAHGOLI, \\ Vali Rasooli SHRABIAN, Mohammadreza ABBASPOUR-GILANDEH \\ University of Mohaghegh Ardabili, Ardabil, Iran
}

\begin{abstract}
Soil friction and soil adhesion increase the implement draft force and energy consumption particularly in the tools that have larger contact area with soil. The main ways of lowering the total draft force of the tillage tools include the use of proper materials in tools structures as well as application of the tools in appropriate soil moisture content condition. This paper investigates the effects of soil moisture content, contact surface material and soil texture on soil friction and soil adhesion coefficients. To measure the coefficients of soil friction and soil adhesion, a measurement system was developed at the University of Mohaghegh Ardabili. Experiments for each soil texture were performed at five levels of soil moisture content and four contact materials of steel, cast iron, rubber, and teflon with three replications. Results have shown that in all soil types, the effects of soil moisture content and contact materials had a significant effect on the coefficient of both soil friction and soil adhesion at the probability level of $1 \%$. The coefficient of friction increased with soil moisture content increment and reached its maximum and then had a drop in the fluid phase. Results have shown that the mean values of soil friction and soil adhesion coefficients were significantly different from the studied soils.
\end{abstract}

Keywords: soil; soil-metal friction; adhesion; moisture; force

The reaction of various soils to the applied forces by tillage tools depend on soil resistance to pressure and shearing, adhesion and friction. These are dynamic properties of soil associated with soil displacement (Gill and Vanden Berg, 1968a; Varga et al., 2013). In general, there are different types of friction occurring in soil dynamics, including: a) soil-metal friction, b) soil-soil friction, and c) soil internal friction. Soil internal friction is usually discussed along with soil shear strength. For calculating soil-soil friction and soil-metal friction, Coulomb's concept is used. Generally, it is assumed that among the soil and implements that move in contact together, friction will be calculated according to Eq. 1:

$$
\mu^{\prime}=\frac{F}{N} \tan \psi
$$

where:

$$
\begin{array}{ll}
\mu^{\prime} & - \text { coefficient of friction } \\
F & - \text { frictional force tangent to sliding surface }(\mathrm{N}) \\
N & - \text { normal force }(\mathrm{N}) \\
\psi & - \text { angle of friction (degree) }
\end{array}
$$

The device for measuring the soil-metal friction is shown in Fig. 1. To determine the coefficient of soil-metal friction, vertical weight was loaded on a slider and frictional force values corresponding to different normal loads were measured and compared with normal load. The slope of the line is a measure of the friction coefficient (Srivastava et al., 2006).

As soil slides on metal, or when the tractor tire moves over the soil surface, adhesive forces between soil and metal or between soil and rubber have a significant effect on the friction force (Kepner et al., 1978). Attraction force between two different materials is defined as adhesion. Adhesion forces between soil and other material are caused by films of their moisture, which is a result of the surface tension of water. Therefore, adhesion force is dependent on the surface tension and moisture tension (Srivastava et al., 2006). Measuring of adhesion as friction has necessitated performing simultaneous measurements of 1) friction stress; 2) soil movement on the metal-soil contact area; and 3) normal load on the surface (Gill and Vanden Berg, 1968a). Fountaine and Payne (1954) added soil adhesion parameter in the soil-metal friction Eq. (1). Therefore, new equation was presented for the first time:

$$
S^{\prime}=C_{a}+\sigma \tan \delta
$$

where:

$\mathrm{S}^{\prime} \quad$ - sliding stress $\left(\mathrm{Nm}^{-2}\right)$

$C_{a} \quad$ - adhesion $\left(\mathrm{Nm}^{-2}\right)$

$\sigma \quad-$ normal stress of frictional surface $\left(\mathrm{Nm}^{-2}\right)$

$\delta \quad-$ angle of soil-metal friction (degree) 


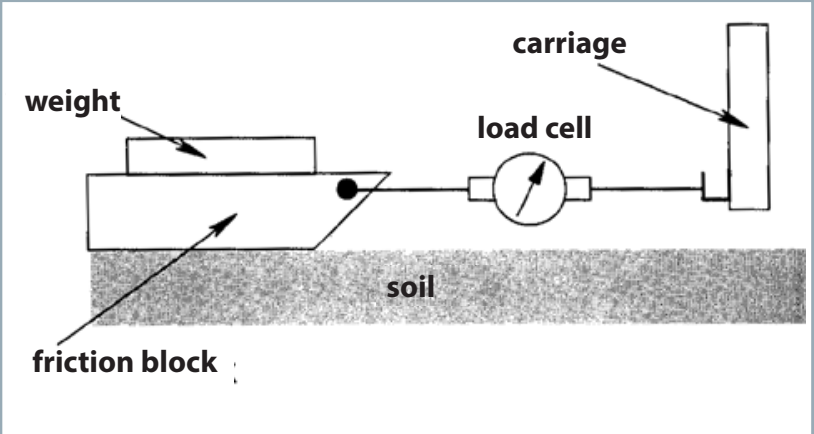

Fig. 1 Measurement of soil-metal friction

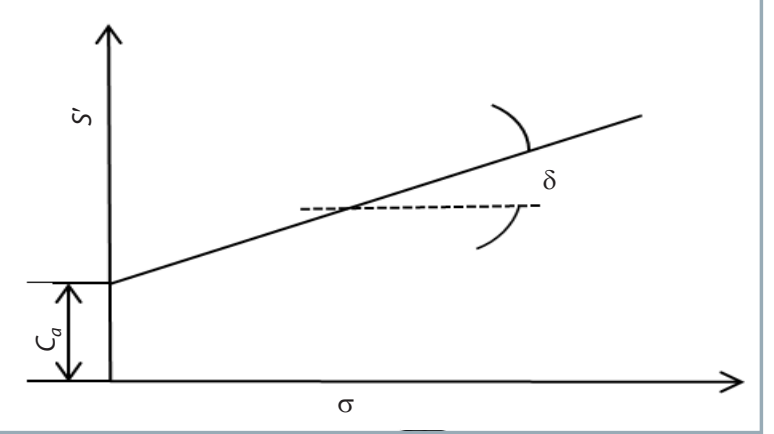

Fig. 2 Failure envelop of soil

This equation is the same as Coulomb's equation (Eq. 3).

$$
S=C+\sigma \tan \phi
$$

As a general rule, a straight or curve line with slight slope can be created by connecting the earned points (Fig. 2). On the $S^{\prime}$ axis, the normal load value is zero and thus the intercept represents adhesion that is desired parameter; the slope of the line expresses the coefficient of sliding friction (Gill and Vanden Berg, 1968a).

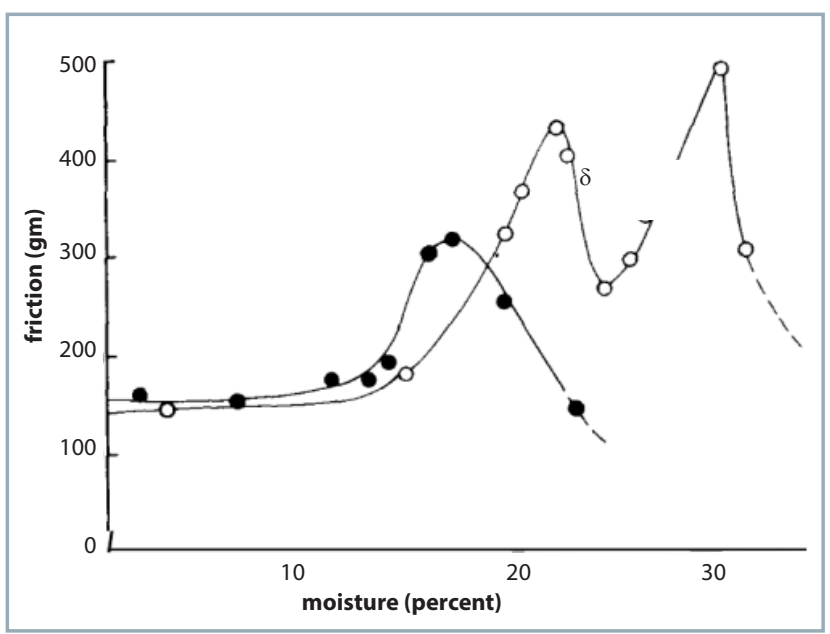

Fig. 3 Impacts of soil moisture content on soil-metal friction coefficient in sandy soil (solid dots) and clay soil (hollow points)

Source: Haines, 1925

Therefore, Eq. 2 is a mathematical model for expressing adhesion. Fountaine and Payne (1954) obtained the values of adhesion and angle of soil-metal friction parameters by means of Eq. 2 and compared them with cohesion and the angle of soil internal friction. Fountaine and Payne (1954) continued their investigation and showed results that adhesion depended on the soil moisture contents and angle of soil-metal friction.

In addition to this, Neal (1966) compared the parameters in Eqs 2 and 3 and the conclusions of their experiments on sandy soil are shown in Table 1. The conclusion was that the coefficient of soil-rubber friction was slightly different from the coefficient of soil internal friction; also the adhesion between soil and rubber was lower than the internal cohesion of the soil. Wong (1989) also obtained the same results as Neal (1966) and Fountaine (1954).

Table 1 Comparison of soil internal shear and soil-rubber frictional parameters

\begin{tabular}{|c|c|c|c|c|}
\hline $\begin{array}{c}\text { Soil moisture } \\
\text { content (\%) }\end{array}$ & $\begin{array}{c}\text { Internal friction angle } \\
\varphi \text { (degrees) }\end{array}$ & $\begin{array}{c}\text { Soil internal cohesion } \\
\mathbf{c}(\mathbf{k P a})\end{array}$ & $\begin{array}{c}\text { Soil-rubber frictional } \\
\text { angle } \delta \text { (degrees) }\end{array}$ & $\begin{array}{c}\text { Soil-rubber adhesion } \\
\mathbf{C}_{\boldsymbol{a}} \mathbf{( k P a )}\end{array}$ \\
\hline 17.9 & 31.9 & 0.62 & 28.4 & 0.55 \\
\hline 13.4 & 29.1 & 2.59 & 29.9 & 0.69 \\
\hline 10.69 & 29.9 & 0.34 & 28.7 & 0.69 \\
\hline 8.73 & 29.9 & 1.38 & 30.0 & 0.69 \\
\hline
\end{tabular}

Source: Neal, 1966

Table 2 Effects of imposed loads by the weight and soil moisture suction on mechanical and frictional properties of different soils

\begin{tabular}{|l||c|c|}
\hline \multirow{2}{*}{ Soil type } & \multicolumn{2}{c|}{ Angle of sliding friction (degrees) } \\
\cline { 2 - 3 } & normal load applied by weight & normal load applied by soil moisture \\
\hline Clay-loam & 35 & 41 \\
\hline Loam & 27 & 26 \\
\hline Sandy-loam & 27 & 31 \\
\hline Sand & 16 & 17 \\
\hline
\end{tabular}




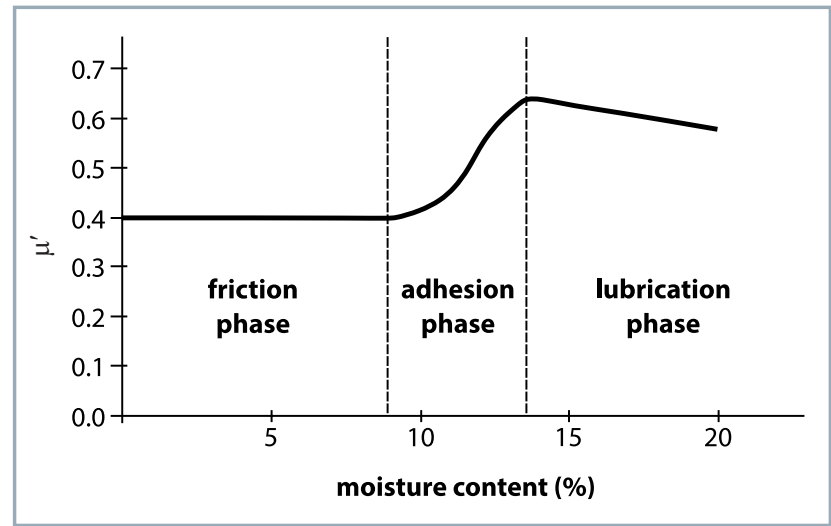

Fig. 4 General phases of soil friction used to determine the soil reaction to soil moisture content Source: Srivastava et al., 2006

Haines (1925) conducted his experiment with a slider over different types of soil with a wide range of moisture content. The coefficient of sliding friction was calculated using the measured data of applied forces for moving slider over the soil. The results are shown in Fig. 3.

As it is illustrated in initial moisture, the part of linear curves indicates the true coefficient of sliding friction, as explained before (Eq. 2). With increasing soil moisture content, adhesion between soil and slider also increases. The increasing in normal load has the same effect on increasing of adhesion force. Furthermore, increasing friction force due to changes in the coefficient of friction is impossible and it can be concluded that changes in normal load result from adhesion (Gill and Vandenberg, 1968).

Fountaine and Payne (1954) asserted that under saturated conditions, adhesion behaves as an increase in normal load; therefore, the normal load on the slider could be used either with weights or with moisture tension. By applying different normal loads to the slider for each method, the friction angle was specified in four different types of soil; the results are shown in Table 2 . Since the friction angles were similar and since the curves of normal load against friction force would pass close to the origin, scholars concluded that adhesion acts as normal load and is, in fact, equivalent to normal loads applied by weight in low-moisture-tension ranges.

Basic phases are classified by Nichols (1931). These phases are largely determined by soil moisture content. General relationship between soil friction on metal surfaces and soil moisture content is presented in Fig. 4. Soil moisture content is related to the surface of moisture layer and moisture tension. Therefore, soil moisture can be used for explanation of soil friction and metal surfaces behaviour in general. According to Nichols's classification (1931), the frictional phase can be observed when the soil is dry. During the frictional phase, adhesive forces are small and the coefficient of friction does not essentially depend on moisture content. With increment in moisture content, adhesion starts to occur and the apparent coefficient of friction increases. In the adhesion phase, the moisture layer between the soil particles and metal is expanded, and thus adhesive forces occur and cause a rapid increment in the apparent coefficient of friction due to moisture content increment. With an increase in moisture and decrease in moisture tension, there probably occurs a situation when adhesion decreases faster than moisture content increases and causes total load reduction. In the final section of the diagram, higher increase in moisture causes friction coefficient reduction because the soil moisture content extends to a level at which free water is present on soil-metal surface and the effect of adhesion is reduced. Since high soil moisture provided lubrication of soil, sliding friction was lowered (Gill and Vanden Berg, 1968b; Srivastava et al., 2006).

Vilde and Tanas (2005) observed a method for determination of soil friction coefficient and specific adhesion. In order to determine the coefficient of friction and the specific adhesion, the soil slipping resistance should be assessed at several different values of the specific pressure between the slipping surfaces. Variations in the soil slipping coefficient have an alternative hyperbolic regress. Based on this assumption, it is possible to determine the coefficients of soil friction and specific adhesion force using the method of least squares.

\section{Material and methods}

To measure the coefficients of friction and adhesion of the soil and materials, a measurement system was developed at the University of Mohaghegh Ardabili; it is shown in Fig. 5. A soil box was moved on two parallel rails by the electric motor, the speed of which was controlled by an inverter (SS-021-1.5K). For measurement of aforementioned coefficients, a piece of constant metal used as a slider was in tangential contact with the soil located inside the soil box during box movement. The 3D slider implements made of steel, cast iron, rubber and teflon had dimensions $5 \times 5 \times$ $0.5 \mathrm{~cm}$. An S-shaped load cell was used to measure the friction force, connected to a data logger model DT800, and all data were loaded to a laptop computer.

Experiments were conducted at an average velocity of $0.035 \mathrm{~m} \cdot \mathrm{s}^{-1}$. The texture of experimental soils was determined by a hydrometric method and their specifications are given in Table 3. In order to investigate the effects of moisture and material, experiments were performed at five levels of soil moisture content for four materials: steel, cast iron, rubber, and teflon, with three replications.

For every implement of metal, the box was filled with soil up to the height of $6 \mathrm{~cm}$, which adjusted moisture and

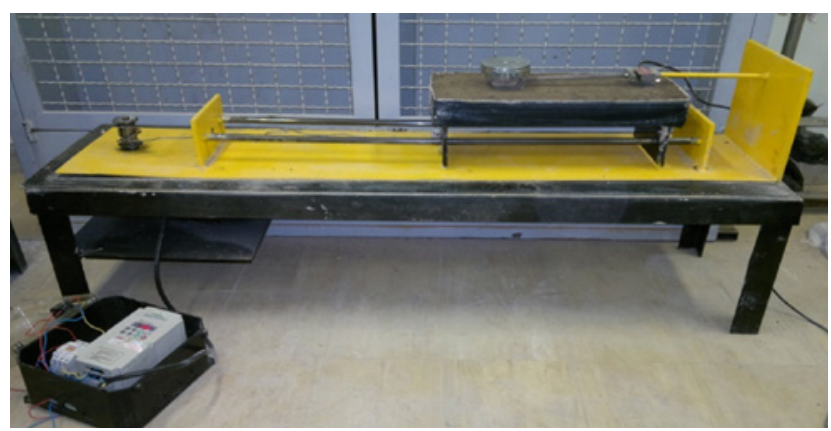

Fig. 5 System developed for measurement of soil-metal friction and adhesion coefficients 
density of $1.3 \mathrm{~g} \cdot \mathrm{cm}^{-3}$, and its surface was straightened with a handy trowel. Soil moisture was determined using Eq. 4:

$$
\theta_{m} \%=\frac{m_{w}-m_{d}}{m_{d}} \cdot 100
$$

Table 3 Determination of the texture of soils used for tests

\begin{tabular}{|l||c|c|c|}
\hline Soil type & Sand (\%) & Loam (\%) & Clay (\%) \\
\hline Loam & 45.66 & 29.33 & 25.008 \\
\hline Loamy-sand & 78.5 & 14.5 & 7 \\
\hline Sandy-loam & 64.5 & 20.8 & 14.5 \\
\hline
\end{tabular}

Normal load on the slider was applied using the weights of $15-25 \mathrm{~N}$. The weight range 5-15 $\mathrm{N}$ was used for lower moisture contents $(6 \%, 7 \%, 11 \%, 12 \%, 13 \%)$. Soils were straightened after each experiment replication with trowel. Adhesion and the coefficient of soil-metal friction were determined using Terzaghi's concept.

$$
\begin{gathered}
\tau=C_{a}+\sigma \tan \delta \\
\frac{F}{A}=C_{a}+\frac{N}{A} \tan \delta \\
F=C_{a} \cdot A+N \tan \delta
\end{gathered}
$$

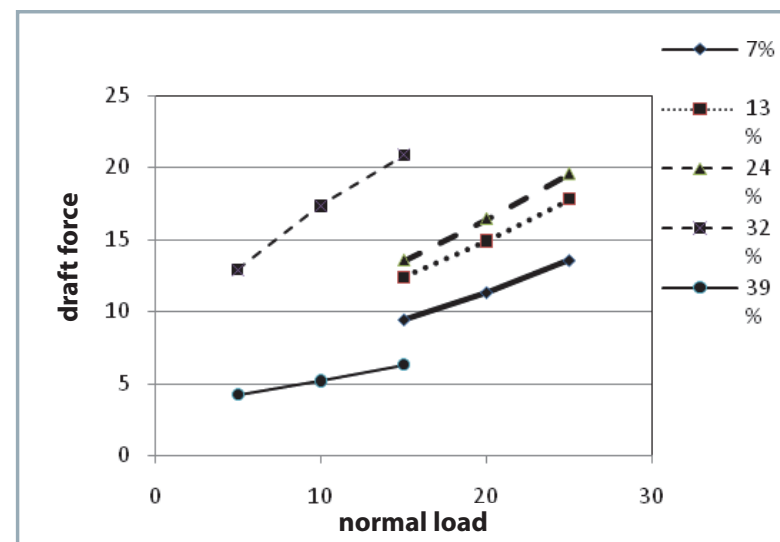

CAST IRON

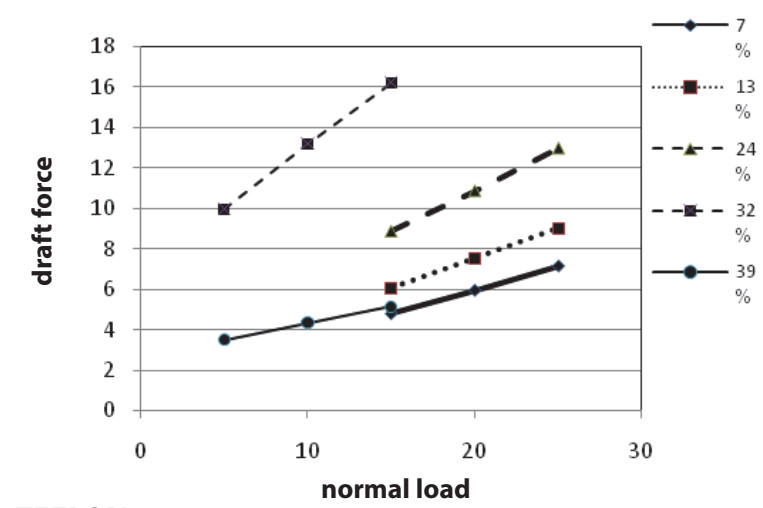

TEFLON

Fig. 6 Tangential force against normal load for four implements at different soil moisture contents for loamy sand soil where:

$$
\begin{array}{ll}
\tau & - \text { shearing stress }\left(\mathrm{N} \cdot \mathrm{m}^{-2}\right) \\
\sigma & - \text { normal stress of frictional surface }\left(\mathrm{N} \cdot \mathrm{m}^{-2}\right) \\
A & - \text { contact surface }(\text { area })\left(\mathrm{m}^{2}\right) \\
F & - \text { shear force }(\mathrm{N}) \\
N & - \text { normal force perpendicular to surface }(\mathrm{N}) \\
C_{a} & - \text { adhesion }\left(\mathrm{N} \cdot \mathrm{m}^{-2}\right) \\
\delta & - \text { angle of soil-metal friction (degrees) }
\end{array}
$$

The tension force versus normal load diagram was drawn, in which the slope of line indicates the coefficient of soil-metal friction and line intercept from $X$ axis shows the adhesion.

\section{Results and discussion}

Fig. 6 represents the results of experiments at different moisture levels in sandy-loam soil. Required draft force was increased by increasing the vertical load on each implement and increasing the moisture content by $32 \%$. By adding water, moisture films were developed between the slider and soil, resulting in adhesion increment. Adhesion increment has the same effect as the increase in slider weight. Therefore, with moisture content increment, adhesive forces cause a rapid increment in the apparent coefficient of friction.

Gill (1968b) clearly found out that some soil sticks to the contacted surface of slider at $32 \%$ moisture content.
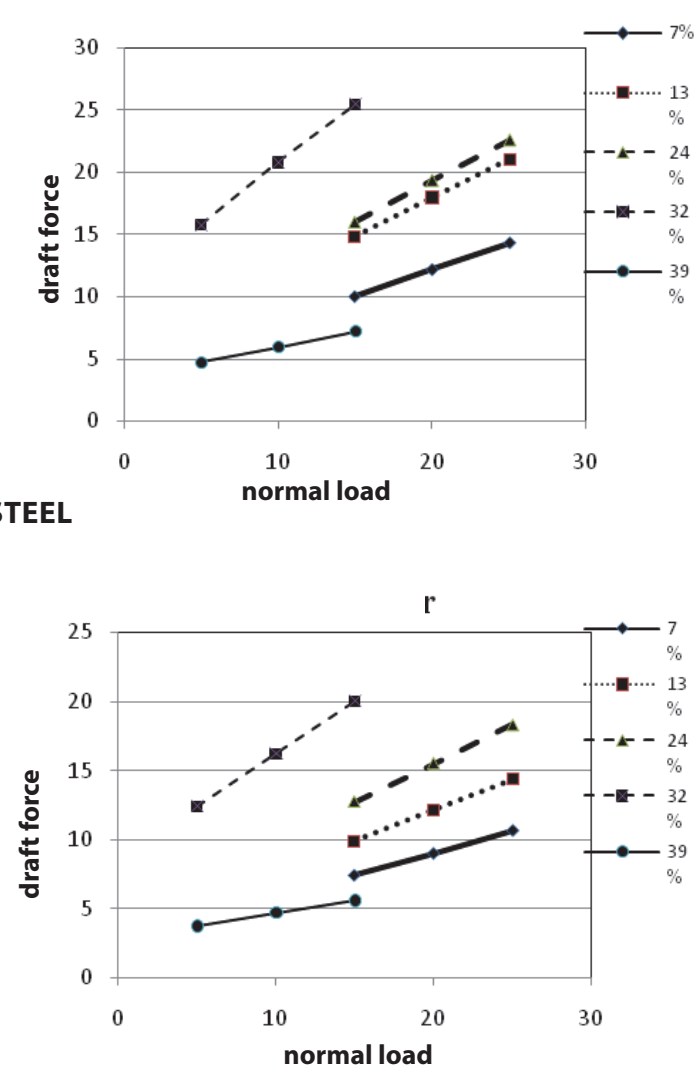

RUBBER 


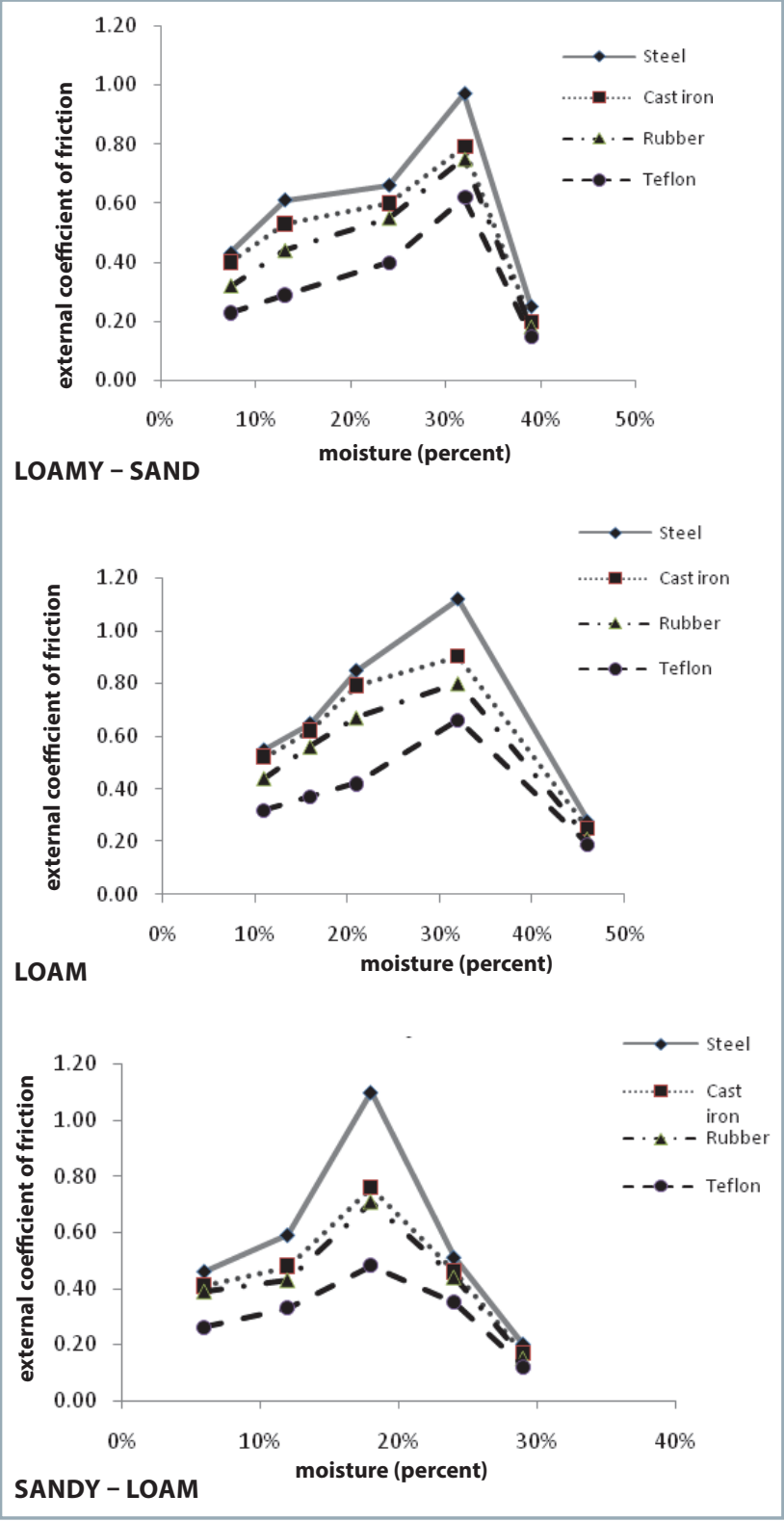

Fig. 7 Effects of soil moisture content on the coefficient of soil-metal friction in different contact implements at the slider speed of $3.5 \mathrm{~cm} \cdot \mathrm{s}^{-1}$

It showed high levels of adhesion at this moisture. With increasing water and when soil moisture content reached $39 \%$ and soil was at its lubrication limit, draft force decreased for all four implements. At this stage, the soil moisture content had reached the level causing the soil lubrication, and in this case, the friction coefficient decreased with increasing of water.

Fig. 7 shows that with the increment in soil moisture content from $11 \%$ to $32 \%$ in loam soil, from $6 \%$ to $29 \%$ in loam-sandy soil, and from $7 \%$ to $32 \%$ in sandy-loam soil, the average of external friction coefficient was significantly increased.

The results of the investigation of the effect of soil moisture content on the coefficient of external friction are consistent with the results obtained by Ahmadi Moghadam et al. (2006). They investigated the effect of five levels of

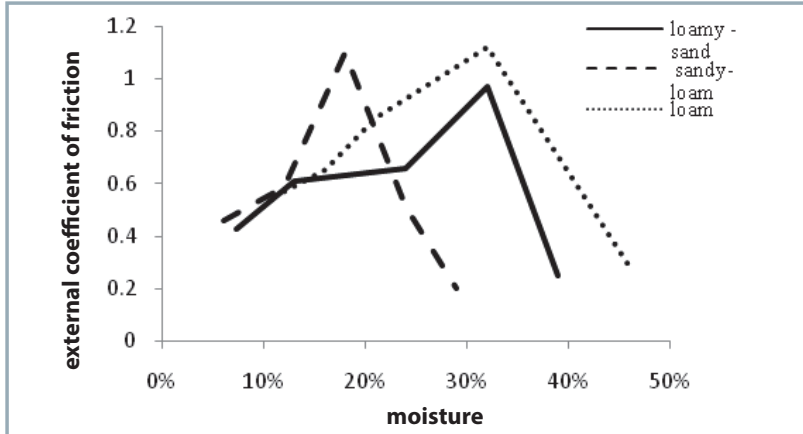

STEEL

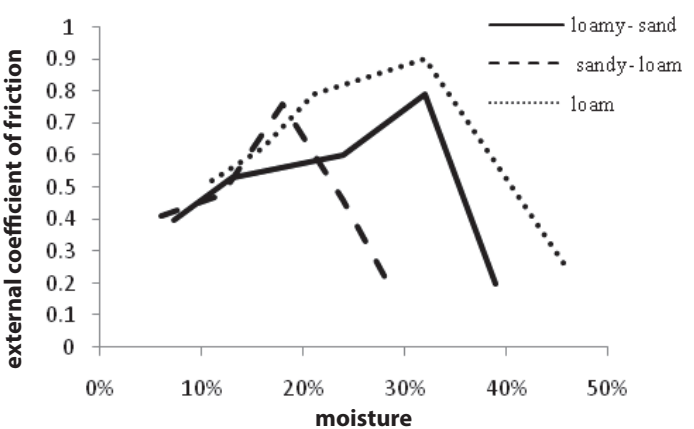

COST IRON

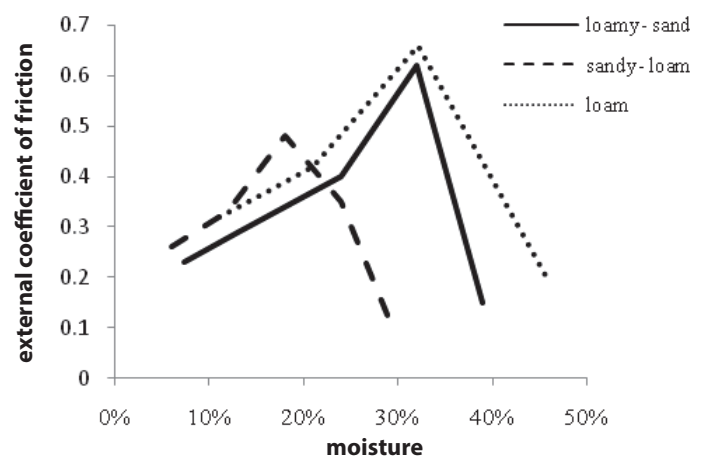

RUBBER

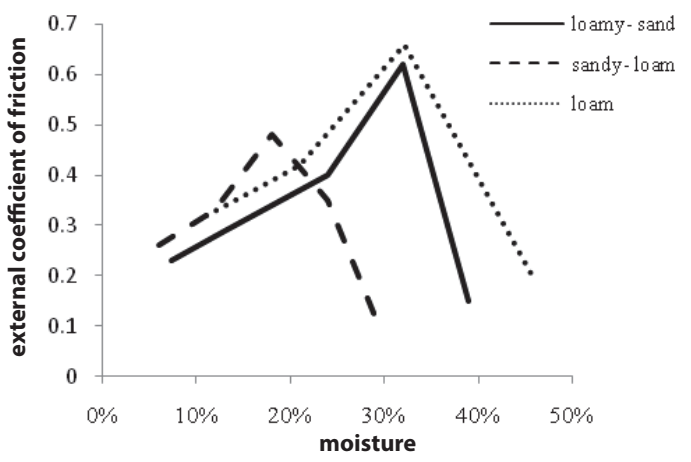

TEFLON

Fig. 8 Effect of soil moisture content on the coefficient of soilmetal friction in different soil texture types at the slider speed of $3.5 \mathrm{~cm} \cdot \mathrm{s}^{-1}$ 
soil moisture content up to the lubrication limit on the coefficient of soil external friction and found that this coefficient increased significantly until moisture reached the lubrication limit. From stated, it can be concluded that adhesion increases with water increment in moisture layers between the soil and the slider. Adhesive force increment operates as an increment in the weight of the slider; therefore, adhesive forces cause the rapid increment in the apparent coefficient of friction with moisture content increment. By adding more water to soils that reached the lubrication limit (loam soil at $46 \%$; sandy loam soil at $39 \%$; loam sand soil at $29 \%$ ), frictional force decreased for all four implements. Whenever the soils moisture content reached the lubrication limit in this stage, the coefficient of friction decreased due to water increment. This result is consistent with Nichols (1931).

As shown in Fig. 8, the amount of soil moisture necessary for reaching the final limit of the friction phase varied at different soil textures for each of the four tested implements. However, they were of the same trend. In all soil textures, with increase in moisture, the coefficient of external friction also increased and passed from the frictional phase to the adhesion phase. By adding more moisture, it passed from the frictional phase limit and entered the lubricating phase in all three soil textures. These results are consistent with the results published by Haines (1925), in which the effect of soil moisture on the coefficient of soil-metal friction in both sandy and clay soils was investigated (Fig. 3).

Results have indicated that steel and teflon show the maximum and minimum adhesion coefficients, respectively, and the difference between these coefficients was significant (Tables 4, 5 and 6). This is because soil type and the surface smoothness of material affect apparent friction and adhesion coefficients. Steel surface absorbs soil moisture and shows higher soil adhesion coefficient in comparison with other surfaces at specific moisture level.

\section{Conclusion}

To measure the coefficients of friction and adhesion of soil and materials, a measurement system was developed at the University of Mohaghegh Ardabili.

In all soil types, the effects of soil moisture content and contact materials had a significant effect on the coefficient of soil friction and soil adhesion at the probability level of $1 \%$.

The coefficient of friction increased with soil moisture content increment and reached the maximum and then had a drop in the fluid phase. The results showed that the mean values of soil friction and soil adhesion coefficients were significantly different for the studied soils.

The results of this study could be applicable in agricultural machinery design and soil and machine system

Table 4 External friction coefficient of sandy loam soil at five moisture content levels and four contact implements at the slider speed of $3.5 \mathrm{~cm} \cdot \mathrm{s}^{-1}$

\begin{tabular}{|c|c|c|c|c|c|}
\hline $\begin{array}{l}\text { Material of } \\
\text { implements }\end{array}$ & $\begin{array}{c}\text { Moisture content } \\
\text { of } 7 \%\end{array}$ & $\begin{array}{c}\text { Moisture content } \\
\text { of } 13 \%\end{array}$ & $\begin{array}{c}\text { Moisture content } \\
\text { of } 24 \%\end{array}$ & $\begin{array}{c}\text { Moisture content } \\
\text { of } 32 \%\end{array}$ & $\begin{array}{c}\text { Moisture content } \\
\text { of } 39 \%\end{array}$ \\
\hline Steel & 0.34 & 0.61 & 0.66 & 0.97 & 0.25 \\
\hline Cost iron & 0.40 & 0.53 & 0.60 & 0.79 & 0.20 \\
\hline Rubber & 0.32 & 0.44 & 0.55 & 0.75 & 0.18 \\
\hline Teflon & 0.23 & 0.29 & 0.40 & 0.69 & 0.15 \\
\hline
\end{tabular}

Table 5 External friction coefficient of loam soil at five soil moisture content levels and four contact implements at the slider speed of $3.5 \mathrm{~cm} \cdot \mathrm{s}^{-1}$

\begin{tabular}{|l||c|c|c|c|c|}
\hline $\begin{array}{l}\text { Material of } \\
\text { implements }\end{array}$ & $\begin{array}{c}\text { Moisture content } \\
\text { of 11\% }\end{array}$ & $\begin{array}{c}\text { Moisture content } \\
\text { of 16\% }\end{array}$ & $\begin{array}{c}\text { Moisture content } \\
\text { of 21\% }\end{array}$ & $\begin{array}{c}\text { Moisture content } \\
\text { of 32\% }\end{array}$ & $\begin{array}{c}\text { Moisture content } \\
\text { of } \mathbf{4 6 \%}\end{array}$ \\
\hline \hline Steel & 0.55 & 0.65 & 0.85 & 1.12 \\
\hline Cost iron & 0.52 & 0.62 & 0.79 & 0.90 \\
\hline Rubber & 0.44 & 0.56 & 0.67 & 0.28 \\
\hline Teflon & 0.32 & 0.37 & 0.42 & 0.21 \\
\hline
\end{tabular}

Table 6 External friction coefficient of loam sand soil at five soil moisture content levels and four contact implements at the slider speed of $3.5 \mathrm{~cm} \cdot \mathrm{s}^{-1}$

\begin{tabular}{|c|c|c|c|c|c|}
\hline $\begin{array}{l}\text { Material of } \\
\text { implements }\end{array}$ & $\begin{array}{c}\text { Moisture content } \\
\text { of } 6 \%\end{array}$ & $\begin{array}{c}\text { Moisture content } \\
\text { of } 12 \%\end{array}$ & $\begin{array}{c}\text { Moisture content } \\
\text { of } 18 \%\end{array}$ & $\begin{array}{c}\text { Moisture content } \\
\text { of } 24 \%\end{array}$ & $\begin{array}{c}\text { Moisture content } \\
\text { of } 29 \%\end{array}$ \\
\hline Steel & 0.46 & 0.59 & 1.1 & 0.51 & 0.20 \\
\hline Cost iron & 0.41 & 0.48 & 0.76 & 0.46 & 0.17 \\
\hline Rubber & 0.39 & 0.43 & 0.71 & 0.44 & 0.15 \\
\hline Teflon & 0.26 & 0.33 & 0.48 & 0.35 & 0.12 \\
\hline
\end{tabular}


modelling such as dynamic simulation of the tire and offroad soils.

\section{References}

AHMADI MOGHADAM, P. - ATAEIYAN, P. - AZIMI, S. 2006. Design, construction and evaluation of soil internal friction angle and soil adhesion measurement device. In Proceedings of the Fifth National Congress of Agricultural Machinery Engineering and Mechanization, Mashhad, Iran.

FOUNTAINE, E. R. 1954. Investigations into the mechanism of soil adhesion. In European Journal of Soil Science, vol. 5, no. 2, pp. 251-263.

FOUNTAINE, E. R. - PAYNE, P. C. J. 1954. Causes of non-scouring in soil working implements. In Fifth International Congress of Soil Science, Leopoldville, vol. 2, pp. 35-45.

GILL, W. R. - VANDEN BERG, G. E. 1968a. Assessment of the Dynamic Properties of Soils. Chapter 3. In Soil Dynamics in Tillage and Traction, Agriculture Handbook, no. 316, pp. 55-116. Washington, D.C. : U.S. Government Printing Office.

GILL, W. R. - VANDEN BERG, G. E. 1968b. Dynamic Properties of Soils. Chapter 2. In Soil Dynamics in Tillage and Traction, Agriculture Handbook, no. 316, pp. 14-116. Washington, D.C. : U.S. Government Printing Office.

HAINES, W. B. 1925. Studies in the physical properties of soil. I. Mechanical properties concerned in cultivation. In Journal of Agricultural Sciences, vol. 15, pp. 178-200.
KEPNER, R. A. - BAINER, R. - BARGER, E. L. 1978. Principles of Farm Machinery. $3^{\text {rd }}$ ed. Avi Publishing Co Inc. ISBN 087055252X.

NEAL, M. S. 1966. Friction and adhesion between soil and rubber. In Journal of Agricultural Engineering Research, vol. 11 no. 2, pp. 108-112.

NICHOLS, M. L. 1931. The dynamic properties of soil II: Soil and metal friction. In Journal of Agricultural Engineering, vol. 12, pp. 321-324.

SRIVASTAVA, A. K. - GOERING, C. E. - ROHRBACH, R.P.-BUCKMASTER, D. R. 2006. Soil tillage. Chapter 8. In Engineering Principles of Agricultural Machines, $2^{\text {nd }}$ ed., pp. 169-230. St. Joseph, Michigan : ASABE. Copyright American Society of Agricultural and Biological Engineers.

VARGA, F. - MOJŽIŠ, M. - ABRAHÁM, R. 2013. Soil resistance and its impact on tillage depth. In Acta Technologica Agriculturae, vol. 16, no. 1, pp. 26-30.

VILDE, A. - TANAS, W. 2005. Determination of the soil friction coefficient and specific adhesion. In TEKA Komisji Motoryzacji I Energetyki Rolnictwa, vol. 5, pp. 212-216.

WONG, J. Y. 1989. Terramechanics and Off-Road Vehicles Engineering. Elsevier Science Publishers, b. v. Amsterdam. ISBN 9780750685610. 